\title{
IMPLEMENTASI PROGRAM BANTUAN OPERASIONAL SEKOLAH (BOS) PADA SEKOLAH DASAR NO 1 BLAHKIUH KECAMATAN ABIANSEMAL KABUPATEN BADUNG
}

\author{
Oleh: \\ I Gede Hery Gunawan, I Made Sumada \\ Fakultas IImu Sosial dan Humaniora Universitas Ngurah Rai
}

\begin{abstract}
A $\mathbf{B}$
OS adalah program pemerintah yang pada dasarnya adalah untuk penyediaan pendanaan biaya operasi nonpersonalia bagi satuan pendidikan dasar sebagai pelaksana program wajib belajar. Pelaksanaan BOS di Bali juga masih terdapat kesenjangan antara harapan dengan kenyataan, setidaknya hal itu dapat dilihat dari pemberitaan di dunia maya yaitu adanya dugaan korupsi, keterlambatan pencairan dana, manipulasi laporan, kelebihan dan kekurangan dana akibat kesalahan administrasi pendataan siswa, tidak melibatkan komite sekolah sebagai pengontrol, kurangnya sosialisasi, dan masalah lainnya yang terjadi di semua Kabupaten di Bali, salah satunya adalah Kabupaten Badung. Rumusan masalah dalam penelitian ini yaitu 1) Bagaimanakah implementasi program Bantuan Operasional Sekolah (BOS) pada Sekolah Dasar No 1 Blahkiuh ? 2) Apakah kendala dalam implementasi program Bantuan Operasional Sekolah (BOS) pada Sekolah Dasar No 1 Blahkiuh? Pendekatan yang digunakan dalam penelitian adalah pendekatan deskriptif kualitatif. Teori implementasi kebijakan publik yang digunakan dalam penelitian ini adalah Teori Merilee S. Grindle (Suharsono,2011:93) Hasil penelitian menunjukkan bahwa implementasi program Bantuan Operasional Sekolah pada Sekolah Dasar No 1 Blahkiuh belum berjalan dengan maksimal karena dalam hal pelaporan masih sering terjadi keterlambatan yang disebabkan oleh kurangnya koordinasi Kepala Sekolah dengan pegawai bagian administrasi.Kendala dalam implementasi program Bantuan Operasional Sekolah pada Sekolah Dasar No 1 Blahkiuh yaitu kurangnya sosialisasi tentang dana BOS, kurangnya koordinasi dalam pelaporan dana BOS dan rendahnya kualitas sumber daya manusia.
\end{abstract}

Kata Kunci : Implementasi, Bantuan Operasional Sekolah (BOS)

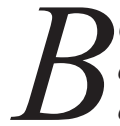

OS is a government program which basically is to provide funding for non-personnel operating costs for basic education units as the implementer of the compulsory education program. The implementation of BOS in Bali also still has a gap between expectations and reality, at least it can be seen from the news in cyberspace, namely allegations of corruption, delays in disbursement of funds, manipulation of reports, excess and lack of funds due to administrative errors in student data collection, not involving school committees as control, lack of socialization, and other problems that occur in all districts in Bali, one of which is Badung Regency. The formulation of the problems in this study are 1) How is the implementation of the School Operational Assistance (BOS) program at Elementary School No 1 Blahkiuh? 2) What are the obstacles in the implementation of the School Operational Assistance (BOS) program at Elementary School No 1 Blahkiuh? The approach used in this research is a qualitative descriptive approach. The theory of public policy implementation used in this research is the Merilee S. Grindle Theory (Suharsono, 2011: 93). The results show that the implementation of the School Operational Assistance program at Elementary School No 1 Blahkiuh has not been running optimally because in reporting, there are often delays. due to the lack of coordination between the principal and administrative staff. Obstacles in the implementation of the School Operational Assistance program at Elementary School No 1 Blahkiuh, namely the lack of socialization about BOS funds, lack of coordination in reporting BOS funds and the low quality of human resources.

Keywords: Implementation, School Operational Assistance (BOS)

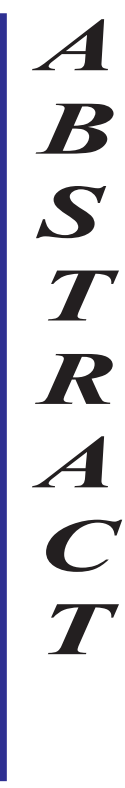




\section{A.PENDAHULUAN}

Penggunaan/pengeluaran dana BOS selama 1 tahun terdapat dalam RKAS (Rencana Kerja Anggaran Sekolah). Pengeluaran dana BOS harus sesuai dengan RKAS sehingga bendahara dan operator sekolah harus menyusun rencana yang benar-benar akurat. Petunjuk teknis Bantuan Operasional Sekolah (BOS) selama tahun 2017-2019 memiliki perbedaan jumlah komponen pembiayaan yaitu:

\section{Tabel 1}

Petunjuk Teknis Bantuan Operasional Sekolah Tahun 2017-2019

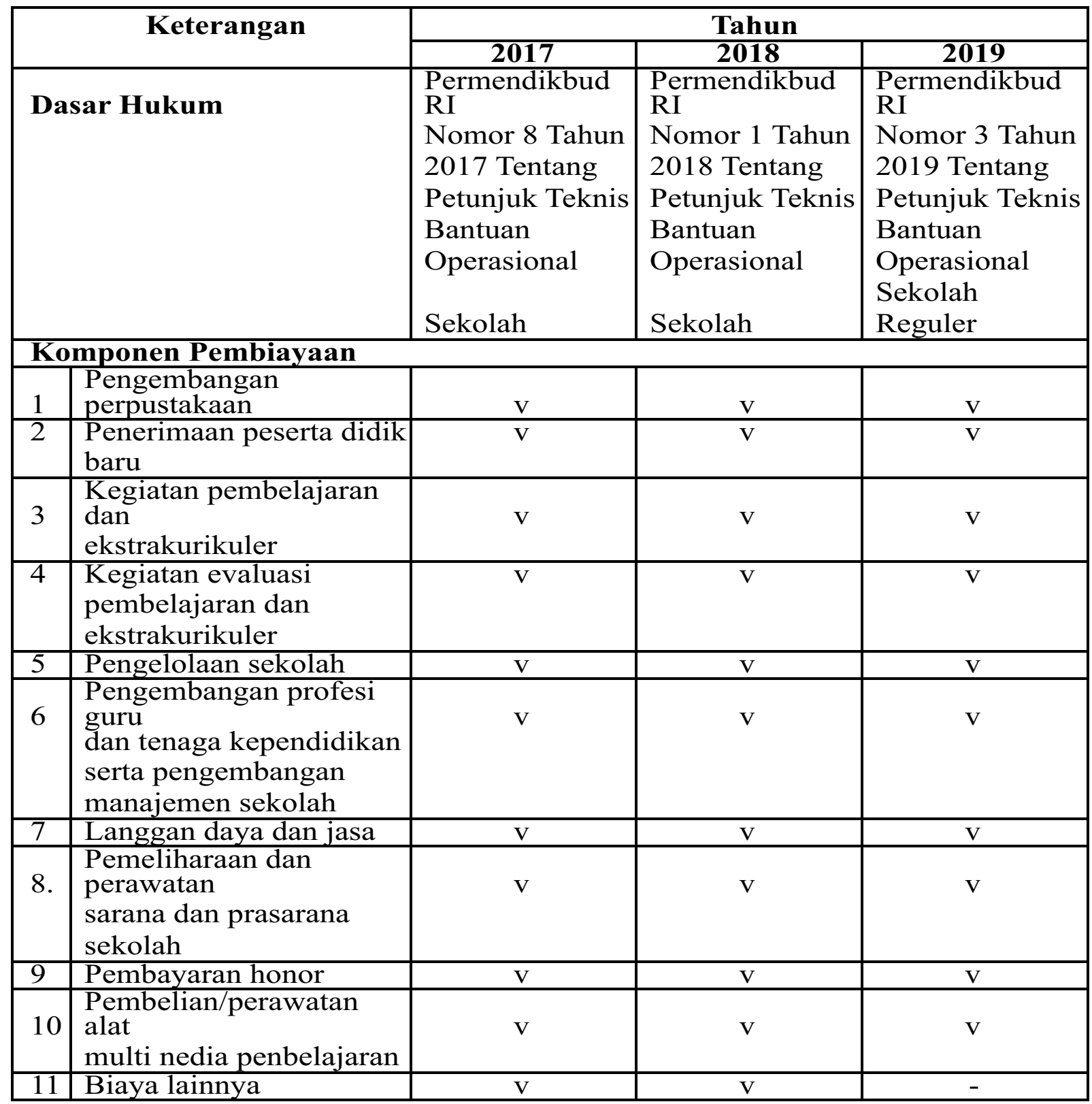

Sumber : Data diolah (2020)

Berdasarkan Tabel 1 di atas menunjukkan bahwa petunjuk teknis bantuan operasional sekolah pada tahun 2017 dan tahun 2018 memiliki jumlah komponen pembiayaan yang sama yaitu 
11 komponen sedangkan pada tahun 2019 berdasarkan Permendikbud RI Nomor 3 Tahun 2019 Tentang Petunjuk Teknis Bantuan Operasional Sekolah Reguler menjelaskan bahwa jumlah komponen pembiayaan sebanyak 10 komponen. Terdapat 1 komponen biaya yang hilang dan $3 \mathrm{sub}$ komponen tersebut ada yang dihilangkan dan ada yang digabungkan ke dalam kategori komponen yang sesuai. Komponen yang hilang tersebut adalah "Biaya Lainnya" dengan sub komponen yaitu :

a. Alat peraga pendidikan yang mendukung kurikulum yang diberlakukan oleh pemerintah pusat. Sub komponen ini dimasukkan ke dalam komponen "Kegiatan Pembelajaran dan Ekstrakurikuler"

b. Pembangunan jamban/WC beserta sanitasinya, hanya bagi sekolah yang belum memiliki prasarana tersebut. Sub komponen ini dimasukkan ke dalam komponen "Pemeliharaan Sarana dan Prasaran Sekolah".

c. Mesin ketik untuk kebutuhan kantor. Sub komponen ini tidak tercantum dalam komponen pembiayaan pada petunjuk teknik bantuan operasional sekolah tahun 2019.

Perbedaan petunjuk teknis tersebut berarti pada tahun 2019 terdapat penyusutan komponen pembiayaan dengan bantuan operasional sekolah atau penyederhanaan komponen pembiayaan tetapi tetap dengan tujuan yang sama yaitu untuk meningkatkan kualitas pendidikan.

Pelaksanaan program BOS belum dapat berjalan dengan baik, hal ini karena masih terdapat kendala dalam implementasi dana BOS di Kabupaten Badung seperti yang dimuat dalam website viva.co.id publikasi tanggal 28 April 2009 bahwa adanya penyalahgunaan dana BOS, Kabupaten Badung tercatat melakukan penyalahgunaan dana BOS sebesar Rp 1.200.000.000,00 (1,2 milyar). Temuan BPK menyatakan bahwa penyalahgunaan dana BOS tersebut yaitu dana BOS digunakan untuk biaya transportasi kegiatan rekreasi kepala sekolah dan guru, uang lelah kepala sekolah, pembelian voucher telepon seluler, pemberian yang duka dan karangan bunga acara pisah sambut kepala dinas. Selain itu juga terdapat kesalahpahaman antara pihak pemerintah, sekolah dan masyarakat mengenai aturan penggunaaan BOS misalnya dalam hal pengadaan LKS, padahal penggunaan dan larangan dana BOS sudah diatur dalam peraturan menteri pendidikan dan kebudayaan no 76 tahun 2012, salah satunya melarang dana BOS untuk pembelian LKS, tetapi masyarakat menganggap dana BOS bisa dipakai untuk pembelian LKS, hal ini menandakan masih lemahnya sosialisasi dari pemerintah dan sekolah kepada masyarakat. Adapun data jumlah Sekolah Dasar yang berda di Kabupaten Badung selama tahun 2019 adalah sebagai berikut :

\section{Tabel 2}

\section{Sekolah Dasar Penerima Dana BOS \\ Di Kabupaten Badung Tahun 2018}




\begin{tabular}{|c|l|c|c|c|}
\hline \multirow{2}{*}{ No } & \multirow{2}{*}{ Kecamatan } & \multicolumn{2}{|c|}{ Jumlah Sekolah Dasar } & \multirow{2}{*}{ Total } \\
\cline { 3 - 4 } & & Negeri & Swasta & \\
\hline 1. & Kecamatan Mengwi & 78 & 19 & 97 \\
\hline 2. & Kecamatan Abiansemal & 69 & 8 & 77 \\
\hline 3. & Kecamatan Kuta Selatan & 48 & 29 & 77 \\
\hline 4. & Kecamatan Kuta Utara & 29 & 43 & 72 \\
\hline 5. & Kecamatan Kuta & 25 & 12 & 37 \\
\hline 6. & Kecamatan Petang & 33 & 0 & 33 \\
\hline \multicolumn{2}{r|}{ Total } & 282 & 111 & 393 \\
\hline
\end{tabular}

Sumber : Disdikpora Kabupaten Badung (2020)

Berdasarkan Tabel 2 menunjukkan bahwa Kecamatan Mengwi memiliki jumlah sekolah dasar dengan penerima dana BOS terbanyak yaitu 97 sekolah dan Kecamatan Petang memiliki jumlah sekolah dasar terendah yaitu 33 sekolah dasar.Salah satu sekolah di Kabupaten Badung yang melaksanakan kebijakan Bantuan Operasional Sekolah adalah Sekolah Dasar No 1 Blahkiuh. Implementasi kebijakan Bantuan Operasional Sekolah di Sekolah Dasar No 1 Blahkiuh memiliki masalah yaitu:

a). Penggunaan dana BOS belum sepenuhnya transparan atau dipublikasikan ke orang tua wali/masyarakat2. Kurangnya koordinasi antara kepala sekolah dan bendahara sekolah yang mengakibatkan terlambatnya pelaporan penggunaan dana BOS.

b). Adanya masalah dalam pelaporan dana BOS yaitu pada kualitas sumber daya manusia/pegawai administrasi dana BOS yang terlihat dari ketidaksesuaian laporan dengan laporan akuntansi sesuai dengan PSAK.

c). Adanya anggapan masyarakat tentang "Sekolah Gratis" menjadikan beban bagi pelaksana di sekolah untuk menjelaskan bahwa yang sebenarnya tidak semua itu gratis.

Berdasarkan uraian di atas menunjukkan bahwa masih terdapat masalah yang timbul dalam implementasi program Bantuan Operasional Sekolah (BOS) maka dalam penelitian ini peneliti akan mengkaji Implementasi Program Bantuan Operasional Sekolah (BOS) Pada Sekolah Dasar No 1 Blahkiuh Kecamatan Abiansemal Kabupaten Badung.

\section{B. METODE}

Bentuk penelitian ini adalah deskriptif kualitatif dengan tujuan untuk menggambarkan realitas yang cermat terhadap fenomena yang terjadi untuk memecahkan masalah-masalah berdasarkan fakta yang nampak. Penelitian ini dilaksanakan pada Sekolah Dasar No 1 Blahkiuh yang beralamat di Jalan Kendedes Banjar Benehkawan, Blahkiuh, Kecamatan Abiansemal Kabupaten Badung. 
Dalam penelitian ini instrumen yang digunakan untuk mengumpulkan data mengenai implementasi program Bantuan Operasional Sekolah (BOS) pada Sekolah Dasar No 1 Blahkiuh. Instrumen utama dalam penelitian ini adalah peneliti itu sendiri. Selain itu peneliti dibantu dengan pedoman wawancara sebagai instrumen utama dalam pengumpulan data.

Menurut Sugiyono (2018:81) "Dalam penelitian kualitatif, teknik penentuan informan yang digunakan adalah teknik purposive sampling yaitu teknik pengambilan data dengan pertimbangan tertentu”. Informan penelitian berasal dari wawancara langsung yang disebut sebagai narasumber. Dalam penelitian ini menentukan informan dengan menggunakan teknik purposive sampling yaitu dipilih dengan pertimbangan dan tujuan tertentu yang benar-benar menguasai suatu objek yang peneliti teliti. Adapun jumlah informan yang peneliti ambil adalah 8 (delapan) orang yaitu 3 (tiga) orang guru, 3 (tiga) orang siswa, 1 (satu) orang anggota komite sekolah dan 1 (satu) orang orang tua siswa.Teknik pengumpulan data yaitu observasi, wawancara, studi dokumentasi dan penelusuran online. Menurut Sugiyono (2017:19), “Analisa data dalam penelitian kualitatif dilakukan pada saat pengumpulan data berlangsung dan setelah selesai pengumpulan data dalam periode tertentu, aktivitas dalam analisis data kualitatif dilakukan secara interaktif dan berlangsung secara terus menerus sampai tuntas sehingga datanya seudah jenuh". Aktivitas ini meliputi reduksi data (data reduction), penyajian data (data display) dan penarikan kesimpulan dan verifikasi (conclusion drawing/verification).

\section{C.HASILDAN PEMBAHASAN}

a). Implementasi Program Bantuan Operasional Sekolah (BOS) Pada Sekolah Dasar No 1 Blahkiuh

Implementasi dana BOS di Sekolah Dasar No 1 Blahkiuh akan dianalisis dengan menggunakan Teori Merilee S. Grindle dalam Suharsono (2011: 93). Implemtasi kebijakan merupakan suatu putusan yang dilaksanakan oleh badan - badan administrasi maupun agen - agen. Seperti yang diungkapkan Rohman (2009:133), implementasi kebijakan pendidikan melibatkan perangkat politik, sosial, hukum, maupun administratif/ organisasi dalam rangka mencapai suksesnya implementasi kebijakan pendidikan. Tujuan utama dana bantuan operasional sekolah atau yang biasa disebut BOS merupakan kebijakan yang di keluarkan untuk meringankan beban orang tua siswa dalam pembiayaan pendidikan serta untuk meningkatkan mutu pendidikan itu sendiri di Sekolah Dasar No 1 Blahkiuh.

Bantuan operasional sekolah dibuat pemerintah guna memberikan fasilitas pendidikan yang memadai serta untuk menuntaskan wajib belajar 9 tahun. Menurut PP 48 Tahun 2008 Tentang Pendanaan Pendidikan, biaya non pendidikan personalia adalah biaya untuk bahan atau peralatan pendidikan habis pakai, dan biaya tak langsung berupa daya air,jasa telekomunikasi, pemeliharaan 
sarana dan prasarana, uang lembur, transportasi, konsumsi, pajak dll.

Namun demikian, ada beberapa jenis pembiayaan investasi dan personalia yang diperpolehkan dibiayai dengan dana BOS. Secara detail jenis kegiatan yang boleh dibiayai dari dana BOS. Setiap siswa akan mendapat bantuan dari dan BOS sebesar Rp 800.000,00 pertahunnya. BOS harus memberi kepastian bahwa tidak ada peserta didik miskin putus sekolah karena alasan finansial seperti tidak mampu membeli baju seragam/alat tulis sekolah dan biaya lainnya.

\section{a. Prosedur Pelaksanaan Bantuan Operasional Sekolah}

Prosedur pelaksanaan dana BOS berdasarkan Permendikbud RI Nomor 3 Tahun 2019 Tentang Petunjuk Teknis Bantuan Operasional Sekolah Reguler dan penyaluran dana BOS dilakukan setiap triwulan yaitu Januari-Maret, April-Juni, Juli-September dan Oktober-Desember. Jumlah dana BOS yang diterima oleh Sekolah Dasar No 1 Blahkiuh selama tahun 2017-2019 adalah berbeda-beda tergantung jumlah siswa dari sekolah. Satuan biaya BOS yang diterima oleh Sekolah Dasar No 1 Blahkiuh adalah Rp 800.000,- (delapan ratus ribu rupiah) per 1 peserta didik per 1 (satu) tahun. Prosedur program BOS dibagi menjadi 3 yaitu pengalokasian BOS, penyaluran BOS dan pengambilan BOS. Sekolah harus menyusun laporan secara lengkap dengan ketentuan sebagai berikut:

- Melakukan rekapitulasi realisasi penggunaan dana bos reguler yaitu melakukan rekapitulasi penggunaan dana BOS Reguler berdasarkan standar pengembangan Sekolah dan komponen pembiayaan dana BOS Reguler. Realisasi penggunaan dana yang dilaporkan merupakan seluruh penggunaan dana BOS Reguler yang diterima Sekolah pada tahun berkenaan. Laporan ini dibuat tiap tahap dan ditandatangani oleh Bendahara, kepala Sekolah, dan Komite Sekolah serta disimpan di Sekolah.

- Sekolah yang diselenggarakan oleh Pemerintah Daerah menyampaikan laporan realisasi penggunaan dana BOS Reguler kepada Pemerintah Daerah sesuai dengan ketentuan peraturan perundang-undangan; dan Sekolah harus mempublikasikan semua pelaporan baik penerimaan dan penggunaan dana BOS Reguler kepada masyarakat secara terbuka. Dokumen yang harus dipublikasikan yaitu rekapitulasi dana BOS Reguler berdasarkan komponen pembiayaan. Publikasi laporan dilakukan pada papan informasi Sekolah atau tempat lainnya yang mudah diakses oleh masyarakat atau orang tua siswa.

\section{b. Sasaran Bantuan Operasional Sekolah.}

Sasaran BOS di Kabupaten Badung adalah seluruh Sekolah Dasar, Sekolah Menengah Pertama dan Sekolah Menengah Atas/Kejuruan. Salah satu sekolah dasar yang menjadi sasaran dana BOS adalah Sekolah Dasar No 1 Blahkiuh. 
Sasaran utama dana BOS adalah untuk meringankan beban orang tua siswa dalam hal pembiayaan pendidikan yang semakin mahal, dan peningkatan mutu pendidikan. Sasaran dana BOS pada Sekolah Dasar No 1 Blahkiuh telah tepat sasaran dengan tujuan membantu siswa untuk menuntaskan pendididkan dan memberikan layanan mutu pendidikan yang berkualitas.

\section{c. Pelaksana Atau Implementator Bantuan Operasional Sekolah}

Organisasi pelaksana BOS meliputi Tim Pengarah dan Tim Manajemen Pusat, Provinsi dan Kabupaten/Kota serta Tim Manajemen Sekolah. Tim Manajemen Sekolah terdiri dari Kepala Sekolah sebagai penanggung jawab, Bendahara BOS sekolah, Komite Sekolah, dan Satu orang dari unsur orang tua peserta didik di luar Komite Sekolah yang dipilih oleh Kepala Sekolah dan Komite Sekolah dengan melihat dan mempertimbangkan kredibilitasnya, untuk menghindari terjadinya konflik kepentingan. Pada Sekolah Dasar No 1 Blahkiuh terdapat tim manajemen sekolah dalam pelaksanaan dana BOS dengan penanggung jawab adalah Kepala Sekolah Dasar No 1 Blahkiuh.

Penggunaan dana BOS Reguler hanya untuk kepentingan peningkatan layanan pendidikan di Sekolah dan tidak ada intervensi atau pemotongan dari pihak manapun. Penggunaan dana BOS Reguler harus didasarkan pada kesepakatan dan keputusan bersama antara tim BOS Sekolah, guru, dan Komite Sekolah. Hasil kesepakatan di atas dituangkan secara tertulis dalam bentuk berita acara rapat dan ditandatangani oleh peserta rapat. Kesepakatan penggunaan dana BOS Reguler harus didasarkan pada skala prioritas kebutuhan Satuan Pendidikan, khususnya untuk pengembangan program peningkatan kualitas belajar Peserta Didik.

\section{d. Penggunaan Dana Bantuan Operasional Sekolah.}

Penggunaan dana BOS yang dilakukan disekolah yang menjadi obyek penelitian yaitu Sekolah Dasar No 1 Blahkiuh lebih banyak digunakan untuk penggajian guru dan tenaga tata usaha honorer karena masih terdapat banyaknya guru dan tenaga tata usaha disekolah tersebut yang belum PNS sesuai dengan Permendikbud RI Nomor 3 Tahun 2019 Tentang Petunjuk Teknis Bantuan Operasional Sekolah Reguler. Selain itu, dana BOS juga lebih banyak digunakan untuk perawatan sekolah dikarenakan luas tanah dan bangunan sekolah yang cukup luas. Penggunaan dana BOS di Sekolah Dasar No 1 Blahkiuh lebih banyak digunakan untuk fasilitas sekolah yang ada dan kegiatan ekstrakurikuler yang cukup banyak disekolah tersebut. Cukup banyaknya fasilitas disekolah membutuhkan biaya yang tidak sedikit, karena tidak hanya pembelian fasilitas yang membutuhkan biaya tetapi perawatannya juga membutuhkan biaya. Selain itu, kegiatan ekstrakurikuler yang cukup banyak juga membutuhkan biaya yang tidak sedikit salah satunya untuk membeli alat peraga ataupun penggajian pelatih untuk ekstrakurikuler tertentu. Hal ini menunjukkan bahwa penggunaan dana BOS pada Sekolah Dasar No 1 Blahkiuh telah disesuaikan dengan Permendikbud RI Nomor 3 
Tahun 2019 Tentang Petunjuk Teknis Bantuan Operasional Sekolah Reguler.

\section{b). Kendala Dalam Implementasi Program Bantuan Operasional Sekolah (BOS) Pada Sekolah Dasar No 1 Blahkiuh.}

\section{a. Kurangnya Sosialisasi Tentang Dana BOS.}

Menurut Sari (2009), sosialisasi didefinisikan sebagai proses penanaman atau transfer kebiasaan atau nilai dan aturan dari satu generasi ke generasi lainnya dalam sebuah kelompok atau masyarakat. Penggunaan dana BOS harus transparan dan diinformasikan kepada orang tua siswa. Tetapi karena kurangnya sosialisasi tentang dana BOS menimbulkan adanya persepsi yang berbeda tentang sasaran dan tujuan penggunaan dana BOS. Timbulnya persepsi berbeda tentang penggunaan dana BOS dari orang tua/wali siswa Sekolah Dasar No 1 Blahkiuh yang disebabkan karena kurangnya sosialisasi. Selain itu laporan tentang dana BOS yang di tempel di mading sekolah, banyak siswa yang tidak memperhatikan, bahkan tidak mengetahui laporan tersebut padahal dalam buku petunjuk teknis BOS di sebutkan bahwa penggunaan dana BOS diumumkan di papan pengumuman (Formulir BOS-04). Selain itu, laporan yang di tempel juga kurang efektif bila dijadikan satu-satunya media komunikasi dengan orang tua, karena orang tua siswa tidak berada di lingkungan sekolah, sehingga mereka tidak dapat melihat laporan tersebut.

Tipe sosialisasi yang dapat diterapkan di Sekolah Dasar No 1 Blahkiuh adalah tipe sosialisasi formal sesuai dengan pendapat ahli Berger dan Lukma (2009:201) bahwa “Tipe sosialisasi formal yaitu sosialisasi yang terbentuk melalui lembaga yang dibentuk oleh pemerintah dan masyarakat yang memiliki tugas khusus dalam mensosialisasi nilai, norma dan perananperanan yang harus dipelajari oleh masyarakat”.

\section{b. Kurangnya Koordinasi Dalam Pelaporan Dana BOS.}

Dalam sebuah organisasi setiap pimpinan perlu untuk mengkoordinasikan kegiatan kepada anggota organisasi yang diberikan dalam menyelesaikan tugas. Dengan adanya penyampaian informasi yang jelas, pengkomunikasian yang tepat, dan pembagian pekerjaan kepada para pegawai administrasi oleh Kepala Sekolah maka setiap individu pegawai akan mengerjakannya sesuai dengan wewenang yang diterima Menurut Hasibuan (2009:85), "Koordinasi adalah kegiatan mengarahkan, mengintegrasikan, dan mengkoordinasikan unsur-unsur manajemen dan pekerjaanpekerjaan para bawahan dalam mencapai tujuan organisasi”.

Pada sekolah Dasar No 1 Blahkiuh menunjukkan masih kurangnya koordinasi yang berpengaruh pada pelaporan penggunaan dana BOS. Pelaporan atas penggunaan dana BOS Reguler harus dilaporkan oleh tim BOS sekolah setiap tahap dana BOS tersebut cair yaitu setiap 3 bulan, apabila sekolah tidak melaporkan dana BOS maka penyaluran dana BOS tahap berikutnya tidak da 
pat dilakukan. Kurangnya koordinasi dalam hal ini koordinasi penggunaan dana BOS antaraKepala Sekolah dan Bendahara sekolah menimbulkan keterlambatan dalam pelaporan.

\section{c. Rendahnya Kualitas Sumber Daya Manusia}

Kualitas sumber daya manusia dibutuhkan sesuai dengan beban kerja yang dimiliki untuk menghindari keterlambatan dalam penyelesaian tugas. Sesuai dengan pendapat Pasolong (2013:5) mengemukakan bahwa "Kualitas Sumber Daya Manusia merupakan tenaga kerja yang memilki kompetensi pengetahuan, keterampilan dan moral yang tinggi”.

Kualitas sumber daya manusia menyangkut mutu dari tenaga kerja yang menyangkut kemampuan, baik berupa kemampuan fisik, kemampuan intelektual (pengetahuan), maupun kemampuan psikologis (mental) (Sedamaryanti, 2009:27). Seperti halnya pada Sekolah Dasar No 1 Blahkiuh, kualitas sumber daya manusia atau pegawai administrasi dana BOS yang masih rendah menimbulkan adanya keterlambatan penyelesaian laporan dana BOS. Kurangnya pemahaman pegawai terhadap Permendikbud RI Nomor 3 Tahun 2019 Tentang Petunjuk Teknis Bantuan Operasional Sekolah Reguler menimbulkan kesalahan dalam memasukkan pos pos rekening keuangan.

\section{D.SIMPULAN}

Berdasarkan hasil analisis data dan pembahasan mengenai implementasi program bantuan operasional sekolah (BOS) pada Sekolah Dasar No 1 Blahkiuh maka dapat disimpulkan bahwa implementasi program Bantuan Operasional Sekolah pada Sekolah Dasar No 1 Blahkiuh belum berjalan dengan maksimal karena dalam hal pelaporan masih sering terjadi keterlambatan yang disebabkan oleh kurangnya koordinasi Kepala Sekolah dengan pegawai bagian administrasi. Kendala dalam implementasi program Bantuan Operasional Sekolah pada Sekolah Dasar No 1 Blahkiuh yaitu kurangnya sosialisasi tentang dana BOS, kurangnya koordinasi dalam pelaporan dana BOS dan rendahnya kualitas sumber daya manusia.

\section{E. Daftar Pustaka.}

Hasibuan, Malayu S.P. 2009. Manajemen Sumber Daya Manusia (Edisi revisi cetakan ke tiga belas). Jakarta: PT Bumi Aksara

Nugroho. 2003. Kebijakan Publik Formulasi, Implementasi dan Evaluasi. Jakarta:PT. Elex Media Pasolong. 2013. Kepemimpinan Birokrasi. Bandung : CV.Alfabeta.

Sedarmayanti. 2009. Sumber Daya Manusia dan Produktivitas Kerja. Bandung:CV. Mandar Maju Sugiyono, 2017. Metode Penelitan Kuantitatif dan Kualitatif. Bandung : Alfabeta ,2018. Metode Penelitan Kuantitatif dan Kualitatif. Bandung :Alfabeta

Permendikbud RI Nomor 8 Tahun 2017 Tentang Petunjuk Teknis Bantuan Operasional Sekolah Permendikbud RI Nomor 1 Tahun 2018 Tentang Petunjuk Teknis Bantuan Operasional Sekolah 